УДК 338.262

DOI 10.18101/2304-4446-2020-1-40-54

\title{
ОСОБЕННОСТИ РЕГИОНАЛЬНОЙ СИСТЕМЫ РЕГУЛИРОВАНИЯ ИНОСТРАННОЙ ТРУДОВОЙ МИГРАЦИИ
}

\author{
(c) Родионова Дарья Николаевна
}

кандидат социологических наук, доцент

E-mail: rodar79@mail.ru

(C) Хайхадаева Октябрина Дмитриевна

доктор экономических наук, доцент

E-mail: okhaikh@mail.ru

(C) Дугарова Альбина Аюшеевна

кандидат политических наук, доцент

E-mail: albinabur@mail.ru

Бурятский государственный университет имени Доржи Банзарова

Россия, 670000, г. Улан-Удэ, ул. Смолина, 24а

Отличительной чертой миграции является намерение гражданина переменить местожительство с целью улучшения своего социального положения. Для полного раскрытия понятия миграции важен момент окончательности перемены места жительства, намерение на прежнее место больше не возвращаться. Существует множество механизмов, которые могли бы инициировать процессы миграции. Такие последствия затрагивают несколько сторон человеческой жизни, включая сферы общественной жизни, религии, культуры, экономики, политики. Эти последствия обязательно происходят в двух местах: в начальной точке миграции, откуда возможно мигранты уезжают, и в пункте назначения. Миграция рабочей силы, или трудовая миграция населения, сегодня представляет собой одну из особых форм передвижения населения с целью трудоустройства. В статье совместно рассмотрены процессы внутренней и международной миграции, в частности трудовой, в региональном аспекте. Официальные источники статистической и аналитической информации, также обзор соответствующих исследований позволяют определить особенности трудовой миграции населения как количественно сопоставимые с выраженной региональной спецификой.

Ключевые слова: миграция; миграционная политика; трудовая миграция; иностранная рабочая сила; трудовые ресурсы.

\section{Для цитирования}

Родионова Д. Н., Хайхадаева О. Д., Дугарова А. А. Особенности региональной системы регулирования иностранной трудовой миграцией // Вестник Бурятского государственного университета. Экономика и менеджмент. 2020. № 1. С. 40-54.

Современные миграционные процессы имеют характерные черты процессов глобализации, охватив все континенты, страны и социальные группы. На сегодняшний день миграция является особым фактором и причиной для тех или иных социально-экономических изменений.

Трудовая миграция как часть общего понятия «миграция», в отличие от других видов миграции, характеризуется тем, что это прежде всего активные граж- 
Д. Н. Родионова, О. Д. Хайхадаева, А. А. Дугарова. Особенности региональной системы регулирования иностранной трудовой миграции

дане в трудоспособном возрасте, обладающие физическим и интеллектуальным развитием, основная цель которых - найти подходящую работу с относительно высокой заработной платой, удовлетворяющей их потребности. Трудовые миграционные процессы выполняют важную функцию: перераспределяют население, компенсируя нехватку трудовых ресурсов в одних регионах (как правило, в более экономически развитых странах) и уменьшают их избыток в других ${ }^{1}$. Стоит отметить, что международно признанного статистического определения трудовой миграции не существует. Однако основными участниками трудовой миграции являются трудящиеся-мигранты, которых Международная организация труда (МОТ) определяет как: «...все международные мигранты, которые в настоящее время работают или не имеют работы и ищут работу в своей нынешней стране проживания».

Измерение миграции в ее многообразии, разработка статистики востребованы не только среди ученых в области миграции, они, прежде всего, необходимы для принятия научно обоснованных решений в области миграционной (и иной) политики.

Факторы, влияющие на миграцию в России, варьируются в зависимости от вида миграции: международная миграция, межрегиональная миграция или миграция внутри региона. Миграция также подразделяется на постоянную миграцию и регулярную возвратную миграцию (ежедневная, еженедельная или сезонная). На сегодняшний день проведены обширные исследования в рамках изучения движущих мотивов оттока мигрантов и привлекательности регионовреципиентов, которые могут быть сгруппированы в основном с природной и социально-экономической точек зрения.

Социально-экономические условия являются наиболее важной движущей силой миграции, из них самые распространенные - более широкие возможности для получения высшего образования в регионах, где представлен выбор в учебных заведениях. Поиск лучших экономических условий является основной причиной миграции в настоящее время, особенно трудовой миграции, включая такие факторы, как заработная плата, возможности трудоустройства, масштаб рынка труда и так далее. В макроэкономическом масштабе Ю. Андриенко и С. Гуриев, изучая межрегиональную миграцию, обнаружили, что наблюдается значительная степень корреляции между безработицей и уровнем бедности в стране происхождения и числом выбывающих из этого региона, что свидетельствует о том, что региональные экономические условия и рыночные масштабы играют важную роль в возникновении миграционных процессов населения [1].

Влияние экономических условий для миграции имеют региональные различия. Исследование С. Сардадвар и Е. Вакуленко показывает, что потенциальный рынок труда имеет большую значимость, чем получение непосредственного дохода [3]. На микроуровне А. Махровой и другими установлено, что пространственная социально-экономическая поляризация главным образом реализуется в возможности трудоустройства, размера заработной платы и вынуждает население перемещаться из экономически депрессивных регионов или городов в более

${ }^{1}$ URL: http://government.ru/news/34920/https://cyberleninka.ru/article/n/suschnost-trudovoymigratsii-kak-ekonomicheskoy-kategorii-i-ee-znachenie-dlya-sotsialno-ekonomicheskogorazvitiya-regiona/viewer (дата обращения: 12.01.2020). 
благоприятные территории. В свою очередь, эта закономерность ухудшает в целом социально-экономическую ситуацию в стране, тем самым усиливая пространственную поляризацию [2].

В Республике Бурятия в структуре миграционных процессов преобладает отток населения из региона. При этом среди выезжающих на постоянное место жительства из республики доминирует молодое трудоспособное население.

Таблица 1

Распределение мигрантов по основным возрастным группам*

\begin{tabular}{|c|c|c|c|c|c|c|}
\hline \multirow[t]{2}{*}{ Годы } & \multirow{2}{*}{$\begin{array}{c}\text { Прибыв- } \\
\text { шие (всего) }\end{array}$} & \multirow{2}{*}{$\begin{array}{c}\text { Выбывшие } \\
\text { (всего) }\end{array}$} & \multirow{2}{*}{$\begin{array}{c}\text { Миграционный } \\
\text { прирост, убыль } \\
\text { (-) (всего) }\end{array}$} & \multicolumn{3}{|c|}{ В том числе в возрасте } \\
\hline & & & & $\begin{array}{c}\text { моложе } \\
\text { трудоспо- } \\
\text { собного } \\
\end{array}$ & $\begin{array}{l}\text { трудоспо- } \\
\text { собном }\end{array}$ & $\begin{array}{l}\text { старше } \\
\text { трудоспо- } \\
\text { собного } \\
\end{array}$ \\
\hline 2009 & 21366 & 22879 & -1513 & -81 & -1297 & -135 \\
\hline 2010 & 20151 & 23386 & -3235 & -415 & -2626 & -194 \\
\hline 2011 & 30376 & 34731 & -4355 & -751 & -3397 & -207 \\
\hline 2012 & 35191 & 39714 & -4523 & -478 & -3627 & -418 \\
\hline 2013 & 37514 & 41093 & -3579 & -422 & -2867 & -290 \\
\hline 2014 & 40570 & 41846 & -1276 & -123 & -928 & -225 \\
\hline 2015 & 43503 & 45509 & -2006 & -189 & -1762 & -55 \\
\hline 2016 & 43545 & 46758 & -3213 & -487 & -2327 & -399 \\
\hline 2017 & 40551 & 43977 & -3426 & -480 & -2407 & -539 \\
\hline 2018 & 41174 & 45751 & -4577 & -824 & -3087 & -666 \\
\hline
\end{tabular}

* По официальным данным Бурятстата.

Межрегиональная миграция характерна интенсивным оттоком населения в Центральный федеральный округ, особенно в г. Москву и Московскую область, в Сибирский федеральный округ, в Северо-Западный федеральный округ (г. Санкт-Петербург), в регионы Южного федерального округа, в том числе в Краснодарский край, Дальневосточного федерального округа, включая Республику Саха (Якутия).

Таблица 2

Внутрироссийская миграция населения*

\begin{tabular}{|c|c|c|c|c|c|c|c|c|c|c|c|c|}
\hline \multirow[t]{2}{*}{ Годы } & \multirow{2}{*}{$\begin{array}{c}\text { Прибыв- } \\
\text { шие } \\
\text { (всего) }\end{array}$} & \multirow{2}{*}{$\begin{array}{l}\text { Выбыв- } \\
\text { шие } \\
\text { (всего) }\end{array}$} & \multirow{2}{*}{\begin{tabular}{c|} 
Мигра- \\
ционный \\
прирост, \\
убыль \\
(всего)
\end{tabular}} & \multicolumn{9}{|c|}{ Федеральные округа } \\
\hline & & & & 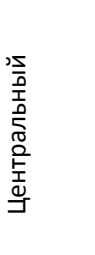 & 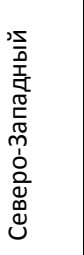 & 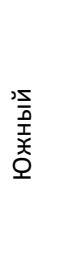 & 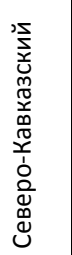 & 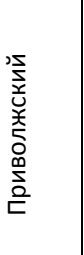 & 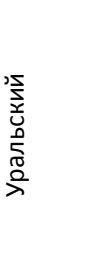 & 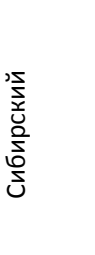 & 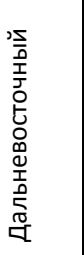 & 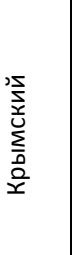 \\
\hline 2009 & 6305 & 8153 & -1848 & -734 & -220 & -254 & -43 & -69 & -140 & -361 & -27 & $x$ \\
\hline 2010 & 6324 & 9768 & -3444 & -960 & -237 & -342 & -57 & -203 & -476 & -1275 & 106 & $x$ \\
\hline 2011 & 8873 & 13636 & -4763 & -914 & -409 & -353 & -4 & -131 & -1146 & -1667 & -139 & $x$ \\
\hline 2012 & 10926 & 15719 & -4793 & -1159 & -383 & -409 & 1 & -165 & -239 & -2097 & -342 & $x$ \\
\hline 2013 & 11755 & 15777 & -4022 & -1250 & -747 & -370 & -5 & -6 & -113 & -1334 & -197 & $x$ \\
\hline 2014 & 12967 & 15046 & -2079 & -739 & -533 & -368 & -54 & -83 & -107 & -331 & 136 & $x$ \\
\hline
\end{tabular}


Д. Н. Родионова, О. Д. Хайхадаева, А. А. Дугарова. Особенности региональной системы регулирования иностранной трудовой миграции

\begin{tabular}{|r|r|r|r|r|r|r|r|r|r|r|r|r|}
\hline 2015 & 13118 & 15793 & -2675 & -904 & -579 & -307 & -32 & -109 & -147 & -247 & -291 & -59 \\
\hline 2016 & 12984 & 16690 & -3706 & -810 & -503 & -509 & -15 & -173 & -93 & -976 & -627 & $\mathrm{x}$ \\
\hline 2017 & 13394 & 16531 & -3137 & -1020 & -687 & -402 & -17 & -174 & -112 & -530 & -195 & $\mathrm{x}$ \\
\hline 2018 & 12863 & 17025 & -4162 & -1140 & -732 & -542 & -17 & -161 & -136 & -1636 & 202 & $\mathrm{x}$ \\
\hline
\end{tabular}

*По официальным данным Бурятстата.

Доля международной миграции в общем миграционном потоке составила $4,1 \%$. Прирост населения республики за счет международной миграции составил 1699 человек: из зарубежных стран в республику прибыло 2194 и выбыло 495 человек. Наибольшую часть в миграционном приросте населения составляют мигранты из Китая - 603, Узбекистана - 376, Киргизии - 288 и Армении 100 человек $^{1}$.

Причины оттока населения из Республики Бурятия носят социальноэкономический характер - низкий уровень заработной платы, высокий уровень бедности, а также высокий уровень социального неравенства и безработицы. Низкооплачиваемые и социально непрестижные вакансии, предлагаемые на рынке труда региона, являются серьезной проблемой для молодых специалистов. В то же время необходимо отметить несоответствие образовательной структуры населения республики потребностям рынка труда, что серьезно сказывается на решении покинуть регион.

Анализ возрастной структуры выезжающих из региона мигрантов показывает, что доля выбывающих детей в возрасте от 14 лет и старше остается высокой и является косвенным показателем безвозвратной миграции. Также наблюдается отрицательная тенденция среди выбывших из республики населения с ученой степенью, с уровнем высшего образования, что показывает ситуацию непривлекательности местного рынка труда для реализации профессиональных компетенций [4]. Данная негативная тенденция сохраняется на протяжении нескольких лет, с годами лишь усиливаясь.

Что касается иностранной трудовой миграции, в 2019 г. на основании предложений субъектов Федерации определена потребность в привлечении иностранных работников в количестве 144583 человека, что составляет $81 \%$ от потребности, определенной на 2018 год. В этом же размере определена квота на выдачу приглашений на въезд в Россию и разрешений на работу для иностранных граждан.

Распределение потребности по приоритетным профессиональноквалификационным группам соответствует увеличению в целом на рынке труда спроса на квалифицированную рабочую силу: $95,1 \%$ потребности, определенной на 2019 год, составляют квалифицированные иностранные работники.

1 URL: http://government.ru/news/34920/https://cyberleninka.ru/article/n/suschnost-trudovoymigratsii-kak-ekonomicheskoy-kategorii-i-ee-znachenie-dlya-sotsialno-ekonomicheskogorazvitiya-regiona/viewer (дата обращения: 12.01.2020). 
Таблица 3

Распределение мигрантов в возрасте 14 лет и старше по уровню образования*

\begin{tabular}{|c|c|c|c|c|c|c|c|c|c|c|c|}
\hline \multirow[b]{3}{*}{$\begin{array}{l}\overline{0} \\
\text { 당 }\end{array}$} & \multirow{3}{*}{ 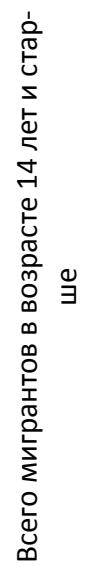 } & \multicolumn{10}{|c|}{ В том числе имели образование } \\
\hline & & \multirow{2}{*}{ 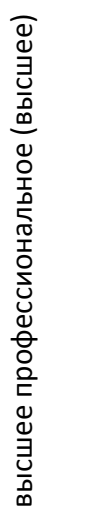 } & \multicolumn{2}{|c|}{$\begin{array}{c}\text { из них } \\
\text { имели } \\
\text { ученую } \\
\text { степень }\end{array}$} & \multirow{2}{*}{ 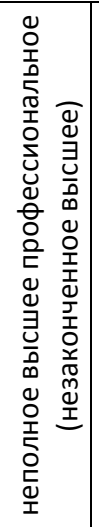 } & \multirow{2}{*}{ 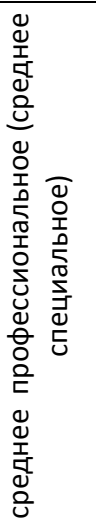 } & \multirow{2}{*}{ 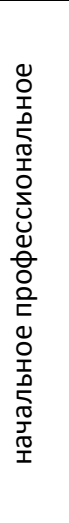 } & \multirow{2}{*}{ 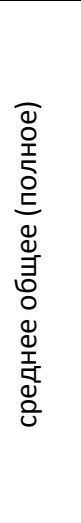 } & \multirow{2}{*}{ 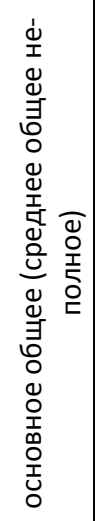 } & \multirow{2}{*}{ 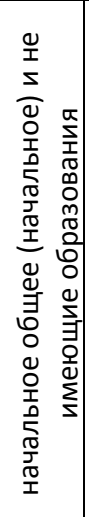 } & \multirow{2}{*}{ 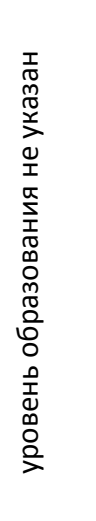 } \\
\hline & & & 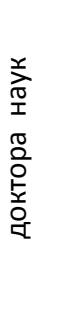 & 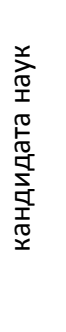 & & & & & & & \\
\hline \multicolumn{12}{|c|}{ Прибывшие } \\
\hline 2014 & 33887 & 9854 & 13 & 29 & 1697 & 9599 & 424 & 7151 & 2298 & 715 & 2149 \\
\hline 2015 & 35689 & 10271 & 5 & 27 & 1599 & 9448 & 410 & 7996 & 2324 & 647 & 2994 \\
\hline 2016 & 35265 & 10728 & 8 & 27 & 1560 & 9301 & 403 & 7071 & 2376 & 632 & 3194 \\
\hline 2017 & 32371 & 9904 & 11 & 31 & 1394 & 8356 & 336 & 6910 & 2383 & 536 & 2552 \\
\hline 2018 & 32822 & 10149 & 8 & 38 & 1212 & 8525 & 327 & 7063 & 2539 & 654 & 2353 \\
\hline \multicolumn{12}{|c|}{ Выбывшие } \\
\hline 2014 & 35055 & 10414 & 15 & 37 & 1710 & 9643 & 442 & 7425 & 2325 & 684 & 2412 \\
\hline 2015 & 37510 & 11088 & 13 & 30 & 1630 & 9477 & 476 & 8503 & 2504 & 657 & 3175 \\
\hline 2016 & 38040 & 11629 & 14 & 33 & 1617 & 9803 & 437 & 7440 & 2603 & 653 & 3858 \\
\hline 2017 & 35359 & 11098 & 14 & 44 & 1457 & 8992 & 346 & 7105 & 2495 & 620 & 3246 \\
\hline 2018 & 36717 & 11656 & 17 & 51 & 1368 & 9435 & 338 & 7569 & 2631 & 718 & 3002 \\
\hline \multicolumn{12}{|c|}{ Миграционный прирост, убыль (-) } \\
\hline 2014 & -1168 & -560 & -2 & -8 & -13 & -44 & -18 & -274 & -27 & 31 & -263 \\
\hline 2015 & -1821 & -817 & -8 & -3 & -31 & -29 & -66 & -507 & -180 & -10 & -181 \\
\hline 2016 & -2775 & -901 & -6 & -6 & -57 & -502 & -34 & -369 & -227 & -21 & -664 \\
\hline 2017 & -2988 & -1194 & -3 & -13 & -63 & -636 & -10 & -195 & -112 & -84 & -694 \\
\hline 2018 & -3895 & -1507 & -9 & -13 & -156 & -910 & -11 & -506 & -92 & -64 & -649 \\
\hline
\end{tabular}

*По официальным данным Бурятстата.

В соответствии с федеральным законом «О правовом положении иностранных граждан в Российской Федерации» от 25.07.2002 № 115 (далее - Ф3-115) Правительству РФ предоставлено право ежегодно с учетом региональных особенностей рынка труда и необходимости приоритетного порядка трудоустройства граждан России устанавливать допустимую долю иностранных работников, используемых в различных отраслях экономики хозяйствующими субъектами, действующими как на территории одного или нескольких субъектов Федерации, так и на всей территории России.

Согласно Ф3-115 работающий иностранный гражданин ежемесячно осуществляет платеж по патенту. Так, по данным МВД по Республике Бурятия, в 2015 г. (до вступления в силу вышеизложенного указа) иностранным гражданам, 
Д. Н. Родионова, О. Д. Хайхадаева, А. А. Дугарова. Особенности региональной системы регулирования иностранной трудовой миграции

прибывшим в Российскую Федерацию в порядке, не требующем получения визы, оформлено 1054 патента, выдано 1024, из них 1020 патентов — для работы у физических лиц, 4 - у юридических лиц. Соответственно большинство иностранных работников были задействованы в деятельности домашних хозяйств.

Согласно сведениям, поступившим из республиканской налоговой службы, сумма авансового платежа по налогу на доходы физических лиц за оформление патента в 2015 г. составила 1 млн 96 тыс. руб. По данным МВД по Республике Бурятия, в 2018 г. иностранным гражданам, прибывшим в Российскую Федерацию в порядке, не требующем получение визы, оформлено 3049 патентов, выдано 2852.

Согласно сведениям, представленным работодателями (заказчиками работ (услуг)) о заключении трудовых (гражданско-правовых) договоров с иностранными гражданами, поступило 1741 уведомление. Количество иностранных работников, привлеченных в деятельность домашних хозяйств, составляет 1061 человек, в обрабатывающем производстве - 200 человек, в строительстве 184 , в торговле - 158, сельском и лесном хозяйстве - 63 , в сфере общественного питания - 31, в области культуры, спорта и развлечений - 15 , в транспортировке и хранении - 11 , в прочих областях -18 .

Согласно сведениям республиканской налоговой службы, сумма поступившего в бюджет республики авансового платежа по налогу на доходы физических лиц за оформление патента в 2018 г. составила 79 млн 937 тыс. руб. Стоимость патента для иностранных работников в Республике Бурятия в рублях в 2015 г. составила 1568,4, 2016 г. — 4269,5, 2017 г. — 4576,9, 2018 г. — 4754,5, 2019 г. — 4876,0. Количество иностранных граждан, работающих на основании патента, составляет $0,63 \%$ численности экономически активного населения республики, что не влияет на уровень регистрируемой безработицы.

Что касается сферы внешней трудовой миграции, то она представлена следующими данными. По сведениям миграционной службы за 2017 г., численность привлеченных в Республику Бурятия иностранных работников, прибывающих в Российскую Федерацию на основании визы, составила 3865 человек. По квоте и вне квоты в Российскую Федерацию приезжают иностранные работники из стран дальнего зарубежья.

Уполномоченным органом в Республике Бурятия по определению потребности привлечения иностранных работников по квотам является Республиканское агентство занятости населения. Вне квоты привлекаются квалифицированные иностранные работники в соответствии с приказом Министерства труда и социальной защиты Российской Федерации от 10.02.2016 № 47н «Об утверждении перечня профессий (специальностей, должностей) иностранных граждан - квалифицированных специалистов, трудоустраивающихся по имеющейся у них профессии (специальности), на которых квоты на выдачу иностранным гражданам, прибывающим в Российскую Федерацию на основании визы, разрешений на работу не распространяются».

В 2017 г. численность иностранной рабочей силы (далее - ИРС) выросла в сравнении с 2016 г. на $33 \%$ (рис. 1). 


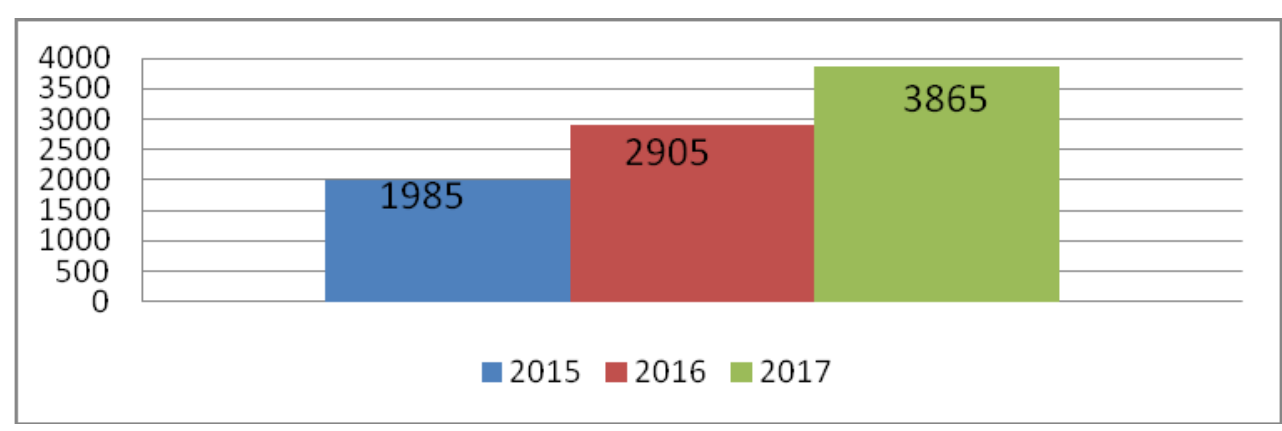

Рис. 1. Динамика привлечения ИРС за 2015-2017 гг.

Распределение, привлеченной в 2016 г. ИРС по видам экономической деятельности, показано в табл. 4.

Таблица 5

Численность ИРС по видам экономической деятельности

\begin{tabular}{|c|c|c|c|}
\hline \multirow[t]{2}{*}{ Показатель } & \multicolumn{3}{|c|}{ Годы } \\
\hline & 2015 & 2016 & 2017 \\
\hline $\begin{array}{l}\text { Численность в Республике Бурятия в отчетном } \\
\text { периоде иностранных работников, прибывших } \\
\text { в Российскую Федерацию на основании визы } \\
\text { (человек) }\end{array}$ & 1985 & 2905 & 3865 \\
\hline $\begin{array}{l}\text { в том числе по видам экономической дея- } \\
\text { тельности: }\end{array}$ & & & \\
\hline строительство & 1110 & 1412 & 1698 \\
\hline $\begin{array}{l}\text { оптовая и розничная торговля, ремонт авто- } \\
\text { транспортных средств, мотоциклов, бытовых } \\
\text { изделий и предметов личного пользования }\end{array}$ & 288 & 371 & 433 \\
\hline сельское хозяйство, охота и лесное хозяйство & 56 & 236 & 306 \\
\hline транспорт и связь & 17 & 85 & 162 \\
\hline добыча полезных ископаемых & 56 & 87 & 113 \\
\hline обрабатывающие производства & 163 & 303 & 372 \\
\hline образование & 11 & 12 & 10 \\
\hline $\begin{array}{l}\text { здравоохранение и предоставление социаль- } \\
\text { ных услуг }\end{array}$ & 23 & 15 & 11 \\
\hline гостиницы и рестораны & 95 & 136 & 164 \\
\hline другие отрасли & 166 & 248 & 596 \\
\hline
\end{tabular}

Такая тенденция объясняется тем, что в регионе преобладает спрос именно на рабочие специальности среди ИРС. С течением времени круг отраслей, в которых задействованы трудовые мигранты, с введением поправок может пополниться за счет спроса на высококвалифицированные кадры.

Наибольший удельный вес в структуре ИРС занимают работники, привлеченные в отрасль «строительство», доля которой в 2017 г. составила 44\%, вместе с тем в сравнении с 2016 г. она снизилась на 5 п.п. 
Д. Н. Родионова, О. Д. Хайхадаева, А. А. Дугарова. Особенности региональной системы регулирования иностранной трудовой миграции

Таблица 5

Удельный вес по отраслям привлеченной ИРС

\begin{tabular}{|c|c|c|c|c|}
\hline Показатель & 2016 & доля, \% & 2017 & доля, \% \\
\hline $\begin{array}{l}\text { Численность привлекаемой в Рес- } \\
\text { публику Бурятия в отчетном пери- } \\
\text { оде иностранной рабочей силы } \\
\text { (человек), в т. ч. по видам эконо- } \\
\text { мической деятельности по визам, в } \\
\text { т. ч. по отраслям, чел. }\end{array}$ & 2905 & 100 & 3865 & 100 \\
\hline строительство & 1412 & 49 & 1698 & 44 \\
\hline $\begin{array}{l}\text { оптовая и розничная торговля, } \\
\text { ремонт автотранспортных средств, } \\
\text { мотоциклов, бытовых изделий и } \\
\text { предметов личного пользования }\end{array}$ & 371 & 13 & 433 & 11 \\
\hline $\begin{array}{l}\text { сельское хозяйство, охота и лесное } \\
\text { хозяйство }\end{array}$ & 236 & 8 & 306 & 8 \\
\hline транспорт и связь & 85 & 3 & 162 & 4 \\
\hline добыча полезных ископаемых & 87 & 3 & 113 & 3 \\
\hline обрабатывающие производства & 303 & 10 & 372 & 10 \\
\hline образование & 12 & 0,4 & 10 & 0,3 \\
\hline $\begin{array}{l}\text { здравоохранение и предоставле- } \\
\text { ние социальных услуг }\end{array}$ & 15 & 1 & 11 & 0,3 \\
\hline гостиницы и рестораны & 136 & 5 & 164 & 4 \\
\hline другие отрасли & 248 & 9 & 596 & 15 \\
\hline
\end{tabular}

Для полного раскрытия предметного поля исследования следует проанализировать эффективность использования ИРС в Республике Бурятия, что определяется в соответствии с Методикой оценки эффективности использования иностранной рабочей силы в Республике Бурятия, утвержденной постановлением Правительства Республики Бурятия от 10.11.2015 № 565. Эффективность определяется по 6 показателям, анализируется эффективность привлечения иностранных работников, прибывающих в Российскую Федерацию на основании визы.

По официальным данным Министерства экономики Республики Бурятия, эффективность привлечения ИРС в разрезе показателей представлена следующим образом:

1. Темп роста вклада иностранных работников в производство товаров и услуг, в \% не менее 100 к предыдущему году.

В целом за 2017 г. в Республике Бурятия отгружено товаров собственного производства, выполнено работ и услуг собственными силами на сумму 220781790 тыс. руб., из них вклад ИРС в производство товаров и услуг составил 2139,2 тыс. руб.

В итоге вклад ИРС в производство товаров и услуг в 2017 г. в пересчете на одного привлеченного иностранного работника составил 553,5 тыс. руб., темп роста к предыдущему году - $112,2 \%$, что соответствует критерию эффективности по этому показателю. Данные сведения представлены в таблице 6. 
Вклад ИРС в производство товаров и услуг

\begin{tabular}{|l|c|c|c|}
\hline \multicolumn{1}{|c|}{ Показатель } & \multicolumn{2}{|c|}{ Годы } \\
\cline { 2 - 4 } & 2015 & 2016 & 2017 \\
\hline $\begin{array}{l}\text { Отгружено товаров собственного производства, } \\
\text { выполнено работ и услуг собственными силами, в } \\
\text { текущих ценах (тыс. руб.) }\end{array}$ & 217828741 & 201607697 & 220781790 \\
\hline $\begin{array}{l}\text { Численность привлекаемых в РБ иностранных ра- } \\
\text { ботников, прибывших в РФ на основании визы (чел.) }\end{array}$ & 1985 & 2905 & 3865 \\
\hline $\begin{array}{l}\text { Вклад иностранных работников, прибывающих в } \\
\text { Российскую Федерацию на основании визы, в про- } \\
\text { изводство товаров и услуг (тыс. руб.) }\end{array}$ & 1309,6 & 1433,7 & 2139,2 \\
\hline $\begin{array}{l}\text { Вклад иностранных работников, прибывающих в } \\
\text { Российскую Федерацию на основании визы, в про- } \\
\text { изводство товаров и услуг в пересчете на 1 ино- } \\
\text { странного работника (тыс. руб.) }\end{array}$ & 523,7 & 493,5 & 553,5 \\
\hline $\begin{array}{l}\text { Темп роста вклада ИР в производство товаров и } \\
\text { услуг в пересчете на одного работника (в процентах } \\
\text { к предыдущему году) }\end{array}$ & 109,1 & & \\
\hline
\end{tabular}

2. Отношение вклада ИРС в доходную часть республиканского бюджета к объему расходов республиканского бюджета на содержание и обучение детей иностранных граждан, обучающихся в детских дошкольных учреждениях и школах, не менее $100 \%$.

В виду отсутствия информации о нормативной стоимости содержания детей в дошкольных и школьных учреждениях, а также данных по количеству детей, прибывших с иностранными работниками, проанализировать эффективность по данному показателю не представляется возможной.

3. По параметру, представленному в табл. 7 в отчетном году по сравнению с предыдущим годом, ситуация следующая: по итогам 2016 г. доля иностранных работников в численности занятых в экономике Республики Бурятия составила $0,9 \%$, увеличившись по сравнению с 2016 г. (0,7\%) на 0,2 п.п.

Таблица 7

Изменение доли ИРС в численности занятых в экономике

\begin{tabular}{|c|c|c|c|}
\hline \multirow[t]{2}{*}{ Показатель } & \multicolumn{3}{|c|}{ Годы } \\
\hline & 2015 & 2016 & 2017 \\
\hline $\begin{array}{l}\text { Численность занятых в экономике Республики Бурятия в сред- } \\
\text { нем за год, чел. }\end{array}$ & 412000 & 408500 & 398900 \\
\hline $\begin{array}{l}\text { Численность привлекаемых в РБ иностранных работников, при- } \\
\text { бывших в РФ на основании визы, чел. }\end{array}$ & 1985 & 2905 & 3865 \\
\hline $\begin{array}{l}\text { Совокупная (средняя) для ИРС в численности занятых в экономи- } \\
\text { ке, \% }\end{array}$ & 0,5 & 0,7 & 0,9 \\
\hline
\end{tabular}

4. Разница между количеством вакансий, рассчитанных на одного иностранного работника и численностью безработных по методологии Международной организации труда (табл. 8). 
Д. Н. Родионова, О. Д. Хайхадаева, А. А. Дугарова. Особенности региональной системы регулирования иностранной трудовой миграции

В 2017 г. в Республике Бурятия по сравнению с 2016 г. произошло снижение численности безработных граждан, определяемых по методологии Международной организации труда, с 43,5 до 42,4 тыс. чел. Также произошло увеличение количества вакансий (0,4 тыс. ед.), заявленных в Республиканское агентство занятости, тем не менее критерий эффективности по данному показателю не выполнен, так как совокупное количество вакансий, заявленных работодателями в органы службы занятости населения в течение отчетного периода, в расчете на одного иностранного меньше совокупного числа безработных по методологии МОТ в расчете на одного иностранного работника (ИР).

Таблица 8

Разница между количеством вакансий и численность безработных

\begin{tabular}{|c|c|c|c|}
\hline \multirow[t]{2}{*}{ Показатель } & \multicolumn{3}{|c|}{ Годы } \\
\hline & 2015 & 2016 & 2017 \\
\hline $\begin{array}{l}\text { Общая численность безработных в Республике Бурятия в сред- } \\
\text { нем за год по методологии МОТ (тыс. чел.) }\end{array}$ & 42,4 & 43,5 & 42,4 \\
\hline $\begin{array}{l}\text { Количество вакансий, заявленных в Республиканское агентство } \\
\text { занятости населения в течение года (тыс. ед.) }\end{array}$ & 32,7 & 32,7 & 38,1 \\
\hline $\begin{array}{l}\text { Совокупное (среднее) число безработных по методологии МОТ в } \\
\text { расчете на одного иностранного работника (чел.) }\end{array}$ & 21,2 & 15 & 10,9 \\
\hline $\begin{array}{l}\text { Совокупное (среднее) количество вакансий, заявленных работо- } \\
\text { дателями в органы службы занятости населения в течение отчет- } \\
\text { ного периода, в расчете на одного иностранного работника }\end{array}$ & 16,4 & 11,3 & 9,8 \\
\hline
\end{tabular}

5. В Республике Бурятия в 2017 г. среднемесячная номинальная заработная плата составила 32237 руб., у привлеченных иностранных работников - 28310 руб., рост которого обусловлен изменением отраслевой структуры, привлеченной ИРС. Соотношение средней заработной платы иностранных работников и среднемесячной номинальной начисленной заработной платы в среднем по Республике Бурятия за 2017 г. составило 87,0\% (табл. 9).

Таблица 9

Соотношение средней заработной платы ИР,

прибывших в РФ на основании визы, и среднемесячной номинальной начисленной заработной платы в среднем по РБ, \%

\begin{tabular}{|l|c|c|c|}
\hline \multicolumn{1}{|c|}{ Показатель } & \multicolumn{3}{|c|}{ Годы } \\
\cline { 2 - 4 } & 2015 & 2016 & 2017 \\
\hline $\begin{array}{l}\text { Среднемесячная номинальная начисленная заработ- } \\
\text { ная плата в среднем по Республике Бурятия (в руб.) }\end{array}$ & 28697,8 & 30211 & 32237 \\
\hline $\begin{array}{l}\text { Среднемесячная заработная плата иностранных ра- } \\
\text { ботников по Республике Бурятия (в руб.) }\end{array}$ & 22271 & 19722 & 28310 \\
\hline $\begin{array}{l}\text { Соотношение средней заработной платы иностранных } \\
\text { работников и среднемесячной номинальной начис- } \\
\text { ленной заработной платы в среднем по Республике } \\
\text { Бурятия (\%) }\end{array}$ & & & \\
\hline
\end{tabular}

6. По данным Министерства внутренних дел по Республике Бурятия, количество преступлений, совершенных иностранными гражданами в 2017 г., к предыдущему году снизилось на 5\% (табл. 10). Доля преступлений, совершенных 
иностранными гражданами, в общем количестве предварительно расследованных преступлений выросла с 0,7 до 0,8\%, вследствие снижения общего количества предварительно расследованных преступлений с 15169 до 13051 ед. Тем не менее данный показатель вписывается в параметры эффективности (менее 5\%).

Таблица 10

Доля преступлений, совершенных иностранными гражданами, в общем количестве преступлений на территории РБ, \%

\begin{tabular}{|l|c|c|c|}
\hline \multicolumn{1}{|c|}{ Показатель } & \multicolumn{3}{|c|}{ Годы } \\
\cline { 2 - 4 } & 2015 & 2016 & 2017 \\
\hline $\begin{array}{l}\text { Количество преступлений, совершенных иностранными } \\
\text { гражданами }\end{array}$ & 128 & 108 & 103 \\
\hline $\begin{array}{l}\text { Рост количества преступлений, совершенных иностран- } \\
\text { ными гражданами, к предыдущему году, \% }\end{array}$ & 118,5 & $85 \%$ & $95 \%$ \\
\hline $\begin{array}{l}\text { Удельный вес преступлений, совершенных иностранны- } \\
\begin{array}{l}\text { ми гражданами, в общем количестве предварительно } \\
\text { расследованных преступлений,\% }\end{array}\end{array}$ & 0,8 & 0,7 & 0,8 \\
\hline
\end{tabular}

Таблица 11

Перечень целевых показателей эффективности использования иностранных работников и их контрольные значения

\begin{tabular}{|c|c|c|c|}
\hline $\begin{array}{l}\text { № } \\
\Pi / \Pi\end{array}$ & $\begin{array}{c}\text { Целевой показатель эффективности использования } \\
\text { иностранных работников }\end{array}$ & $\begin{array}{c}\text { Контрольное } \\
\text { значение }\end{array}$ & 2016 г. \\
\hline 1. & $\begin{array}{l}\text { Темп роста вклада иностранных работников (далее - ИР) } \\
\text { в производство товаров и услуг } *\end{array}$ & не менее $100 \%$ & 112,2 \\
\hline 2. & $\begin{array}{l}\text { Отношение вклада ИР в доходную часть республиканско- } \\
\text { го бюджета к объему расходов республиканского бюдже- } \\
\text { та на содержание и обучение детей иностранных граж- } \\
\text { дан, обучающихся в детских дошкольных учреждениях и } \\
\text { школах }\end{array}$ & не менее $100 \%$ & $\begin{array}{l}\text { нет дан- } \\
\text { ных }\end{array}$ \\
\hline 3. & $\begin{array}{l}\text { Изменение доли ИР в численности занятых в экономике в } \\
\text { отчетном году по сравнению с предыдущим годом }\end{array}$ & $\begin{array}{l}\text { уменьшение зна- } \\
\text { чения показателя } \\
\text { или рост не более } \\
\text { чем на } 2 \text { процент- } \\
\text { ных пункта }\end{array}$ & $\begin{array}{l}\text { рост на } 0,2 \\
\text { п.п. }\end{array}$ \\
\hline 4. & $\begin{array}{l}\text { Разница между количеством вакансий и численностью } \\
\text { безработных по методологии МОТ, рассчитанных на од- } \\
\text { ного иностранного работника }\end{array}$ & более 0 & $-1,1$ \\
\hline 5. & $\begin{array}{l}\text { Соотношение средней заработной платы иностранных } \\
\text { работников, прибывших в Российскую Федерацию на } \\
\text { основании визы, и среднемесячной номинальной начис- } \\
\text { ленной заработной платы в среднем по Республике Буря- } \\
\text { тия }\end{array}$ & более 70\% & $87 \%$ \\
\hline 6. & $\begin{array}{l}\text { Доля преступлений, совершенных иностранными граж- } \\
\text { данами, в общем количестве совершенных преступлений } \\
\text { на территории Республики Бурятия }\end{array}$ & менее 5\% & $0,8 \%$ \\
\hline
\end{tabular}

*В пересчете на 1 ИР 
Д. Н. Родионова, О. Д. Хайхадаева, А. А. Дугарова. Особенности региональной системы регулирования иностранной трудовой миграции

По итогам 2017 г. из установленных 6 показателей оценки эффективности использования иностранной рабочей силы в Республике Бурятия исполнено 4, что составляет $66,7 \%$ (табл. 11). В соответствии с методикой оценки эффективности использования иностранной рабочей силы в Республике Бурятия оптимальным считается достижение более $50 \%$ установленных контрольных значений.

Таким образом, в Республике Бурятия, равно как и в других регионах, проводится политика приоритетного трудоустройства местных граждан, что является первоочередной задачей Правительства Республики Бурятия для сдерживания объемов привлечения иностранной рабочей силы.

В этих целях проводится работа по следующим направлениям:

1) квотирование на привлечение иностранной рабочей силы, направленное на снижение привлечения неквалифицированной иностранной силы. Приоритет в данном случае отдается привлечению высококвалифицированных иностранных работников;

2) второе направление - это увеличение стоимости патентов, в республике с 1 января 2018 г. стоимость патента составляла 4754,5 руб., с 1 января 2019 г. 4876 руб., динамика стоимости с распределением стран показана в таблице 12. Как видно, огромную долю составляют выходцы из Узбекистана, Таджикистана и Азербайджана, что говорит о привлекательности республиканского рынка труда для данной категории;

Таблица 12

Количество и стоимость выданных патентов по странам исхода

\begin{tabular}{|c|c|c|c|c|}
\hline Страна исхода & 2015 г. & 2016 г. & 2017 г. & 2018 г. \\
\hline Азербайджан & 69 & 95 & 108 & 130 \\
\hline Армения & - & - & - & - \\
\hline Киргизия & 21 & - & - & - \\
\hline Молдавия & 2 & 1 & 5 & 2 \\
\hline Таджикистан & 88 & 174 & 163 & 292 \\
\hline Узбекистан & 837 & 1471 & 2010 & 2419 \\
\hline Украина & 7 & 62 & 34 & 9 \\
\hline Казахстан & - & - & - & - \\
\hline ЛБГ & - & - & - & - \\
(лица без гражданства) & & & & 2852 \\
\hline ИТОГО & 1024 & 1803 & 2320 & 4755 \\
\hline Стоимость патента & 1568,4 & 4269,48 & 4576,86 & 81924720 \\
\hline Поступило налога в бюджет & 8198330 & 33731764 & 59434860 & \\
\hline
\end{tabular}

3) деятельность в сфере регулирования количества ИРС - это подготовка заявки на квоту по выдаче разрешений на временное проживание (РВП). В ходе проведенного анализа установлено, что процент получения гражданства Российской Федерации иностранными гражданами, проживающими по РВП, не превышает $33 \%$, большая часть иностранных граждан использует РВП в целях трудоустройства на территории России.

С учетом результатов анализа квота на РВП на 2018 г. установлена в количестве 800 человек (2017 г. - 900, 2016 г. - 1200). Размер квоты на выдачу иностранным гражданам разрешений на временное проживание для субъектов Рос- 
сийской Федерации устанавливается Правительством Российской Федерации ежегодно до 30 ноября.

Вместе с тем комплекс мер, реализуемый по регулированию привлечения ИРС, позволяет сдерживать численность привлекаемой иностранной рабочей силы в республике в пределах двух тысяч человек.

В целом же пик трудовой иммиграции в регионе наблюдался в 2008-2012 гг. (13 152 чел.), что связано с развитием строительного бизнеса, ростом числа привлеченных работников в сферы сельского хозяйства, торговли, перерабатывающей промышленности в Республике Бурятия и укреплением региональной экономики. По данным Бурятстата, в связи со спадом в результате последствий экономического кризиса правительство Республики Бурятия вынуждено было снизить потребность экономики в иностранных кадрах, что повлекло за собой снижение квоты на иностранную рабочую силу, и в 2016 г. в наш регион прибыло 4959 трудовых мигрантов, так как в республике резко возрос уровень безработицы.

В Республику Бурятия приезжают трудиться граждане из различных стран. Наибольшее число иностранной рабочей силы в 2013-2016 гг. было привлечено из Китая $(65,2 \%$ общего числа привлеченной ИРС, в 2016 г. численность составила 3234 человека, что на 4116 меньше, чем в 2013 г.), Узбекистана, Украины, Таджикистана и других.

По-прежнему наиболее востребованными на нашем рынке труда остаются рабочие профессии, к примеру, в сфере строительства в Бурятии. По причине фиксации допустимой доли иностранных работников, которые могут осуществлять какую-либо деятельность на территории России, это порядка $20 \%$ общего количества работников. Дефицит в ИРС вызван тем, что в 2014 г. в Бурятии были построены объекты на общую сумму в 2,5 млрд руб. При этом в отрасли задействовано более восьми тысяч человек, из них почти две тысячи являются гражданами Китая. В 2018 г. объем строительства увеличился почти в два раза (порядка 4 млрд руб.), а при этом количество рабочих даже уменьшилось (7,5 тыс. чел.).

Республиканское агентство занятости предоставляет возможность обучиться за государственный счет на бетонщика, арматурщика или каменщика, тем не менее желающих из местного населения мало по причине сложности и трудоемкости. До недавнего времени граждане Китая закрывали данную потребность в кадрах, оказывая квалифицированную помощь.

По уточненным сведениям Министерства труда и социальной защиты РФ о рабочих местах, на которые предполагается привлечение иностранных работников в 2019 г., для республики необходимы такие виды профессий, как заточник деревообрабатывающего инструмента, наладчик деревообрабатывающего оборудования, пилоправ, пильщик, оператор агрегатных линий сортировки и переработки бревен, оператор вальцовочной линии, резчик кирпича и черепицы, оператор на автоматических и полуавтоматических линиях в деревообработке и т. д. Но, как показывает ситуация на рынке труда, подобных предложений в необходимом объеме нет.

Подводя итоги, можем отметить то, что в Республике Бурятия прослеживается миграционная политика по снижению на рынке труда доли иностранных работников. Что, в свою очередь, уберегает местных жителей от конкуренции и явля- 

регулирования иностранной трудовой миграции

ется мерой вынужденной, так как в регионе наблюдается напряженная ситуация на рынке трудовых ресурсов. В республике нехватку иностранной рабочей силы местные предприятия решают с помощью субподрядных организаций, что является не выгодным: республика не дополучает потоки налоговых поступлений в бюджет, а ситуация на рынке труда так и остается напряженной.

С позиции деятельности УМВД Республики Бурятия как одного из ведомственного органа, курирующего миграционные процессы на территории субъекта, одним из его важных направлений деятельности является противодействие нелегальной миграции. В решении данной задачи участвуют различные подразделения полиции. Осуществляется взаимодействие с другими органами исполнительной власти, проводятся совместные оперативно-разыскные и профилактические мероприятия, целевые операции, рейдовые мероприятия, в том числе направленные на выявление в миграционной среде лиц, причастных к экстремистской и террористической деятельности, пресечению фиктивной регистрации мигрантов.

\section{Литература}

1. Andrienko Yu., Guriev S. Determinants of Interregional Mobility in Russia: Evidence from Panel Data. William Davidson Working Paper. 2003. № 551. URL: https://deepblue.lib.umich.edu/ (дата обращения: 12.01.2020).

2. Makhrova A. G., Nefedova T. G., Pallot J. The specifics and spatial structure of circular migration in Russia // Eurasian Geogr. Econ. 2016. № 57. P. 802-818.

3. Sardadvar S., Vakulenko E. A model of interregional migration under the presence of natural resources: Theory and evidence from Russia // Ann. Reg. Sci. 2017. № 59. P. 535-569.

4. Шевцова Е. А., Дмитриева А. К. Миграционная политика Республики Бурятия: сценарные подходы // Вестник Тюменского государственного университета. Социальноэкономические и правовые исследования. 2016. Т. 2, № 2. С. 59-71.

\section{FEATURES OF THE REGIONAL SYSTEM \\ FOR FOREIGN LABOUR MIGRATION CONTROL}

Darya N. Rodionova

Cand. (Sociol.), A/Prof.

E-mail: rodar79@mail.ru

Oktyabrina D. Khaikhadaeva

Dr. Sci. (Econ.), A/Prof.

E-mail: okhaikh@mail.ru

Albina A. Dugarova

Cand. Sci. (Polit.), A/Prof.

E-mail: albinabur@mail.ru

Dorzhi Banzarov Buryat State University

24a Smolina, Ulan-Ude 670000, Russia

A distinctive feature of migration is the person's intention to change place of residence in order to improve his social situation. The concept of migration reveals in the finality of a decision to change place of residence, and the intention not to return to the former place. 
There are many mechanisms that could trigger migration processes. Such consequences affect several aspects of human life, including social sphere, religion, culture, economy, and policy. These consequences necessarily occur in two places: at the starting point of migration, from where migrants leave, and at destination point. Labour migration today is one of the special forms of population movement for the purpose of employment. The article considers the processes of internal and international migration, in particular labour migration, in a regional aspect. Official statistical and analytical sources, as well as a review of relevant studies, allow us to define them as quantitatively comparable with pronounced regional specifics.

Keywords: migration; migration policy; labour migration; foreign labour; labour. 